\title{
CREATING A DECOLONISED CURRICULUM TO ADDRESS FOOD INSECURITY AMONG UNIVERSITY STUDENTS
}

\author{
Oluwakemi Ayodeji Adebayo, Ronicka Mudaly \\ University of KwaZulu-Natal, South Africa \\ E-mail: kadebayo_fds@yahoo.com, mudalyr@ukzn.ac.za
}

\begin{abstract}
A plethora of debates about intellectual imagination regarding decolonised curriculum development has dominated the South African higher education discourses. There is a need to purge Africa of the marginalisation that has been perpetuated by curricula established during the past century. The aim of this research was to add a practical dimension to this discourse, by altering traditional curriculum activities in a biology module, in order to address the issue of food insecurity among university students. In this qualitative inquiry, the following questions were asked: "How can pre-service teachers engage with decolonised curricular activities, in order to address food insecurity among students?" and "What are the consequences of pre-service teachers' engagement with decolonised curricular activities which respond to food insecurity?" Thirty-six pre-service biology teachers and 12 non-biology university students were purposively selected to participate in a food gardening activity. Data were generated using individual interviews, focus group interviews and the development of portfolios. Findings revealed that pre-service teachers' consciousness of the social reality of food insecure students was raised, and their feelings of empowerment to enable others, and themselves, to become self-reliant, were enhanced through decolonised curricular activities. This is significant because it signalled a freeing of pre-service teachers from material and intellectual shackles which is critical to decolonised thought and action. This research has implications for higher education science teacher education modules, which can incorporate science from Western and indigenous sources, to create transformed curricula which are socially responsive and reflect epistemic justice.
\end{abstract}

Keywords: decolonised curriculum, food gardening, indigenous knowledge, qualitative methodology, self-reliance, transformation.

\section{Introduction}

While leading education analysts hotly debate the conceptualisation of curriculum, decolonisation, democratic curricula, epistemicide and anti-colonial struggles, the real, ongoing suffering of some university students whose access to food, a fundamental resource, is impeded. Students starve while researchers and analysts theorise about truths, power, knowledge, values, and so on. Literature is replete with evidence that lack of social capital, epistemological and financial deprivation among university students have influenced their study outcomes negatively (Van Zyl, 2015). Financial deprivation has resulted in students being unable to access affordable housing (Dominguez-Whitehead, 2015). Many of the universities which do provide residence halls exclude the provision of meals and this makes students, especially those who are less privileged, food insecure. Within the South African context, this phenomenon is indicative of food insecurity and starvation in the broader society. Kumo, Omilola and Minsat (2015), who conducted a survey, revealed that people in $23 \%$ of the homes could not get enough food to eat while people in $13 \%$ of homes had experienced starvation. These researchers conceded that food security remains a challenge in South Africa despite various government interventions to ease poverty. 
Oluwakemi Ayodeji ADEBAYO, Ronicka MUDALY. Creating a decolonised curriculum to address food insecurity among university students

\begin{abstract}
PROBLEMS
OF EDUCATION

IN THE $21^{\text {st }}$ CENTURY Vol. 77 , No. 1, 2019

180 While the oppressive triad of class, race and age, and its consequences on student throughput rates and employment opportunities are acknowledged, it is important to depart from the discourse of victimhood, and to explore ways in which university students can be empowered to address the challenge of food insecurity among their peers. This research achieved this by examining pre-service science teachers' transformation and empowerment which occurred as a result of their participation in a project which aimed to develop resilience among residence students. Ways in which the curriculum can be used to address the challenge of food insecurity, by drawing on African indigenous knowledge, are underscored. This is conceptualised as "doing" decolonisation.
\end{abstract}

\title{
Problem of Research
}

Munro, Quayle, Simpson, and Barnsley (2013a), whose study focused on the University of KwaZulu-Natal, showed that students' inability to access a balanced diet was a barrier to their chances of successful completion of their degrees, employment prospects and socio-economic improvement. In this way, the socially-perpetuated loop of poverty tightens.

The problem of this research was how the curriculum can be decolonised in order to address food insecurity among university students.

\section{Research Focus}

Central to this research were the following questions: "How can pre-service teachers engage with decolonised curricular activities, in order to address food insecurity among university students?" and "What are the consequences of pre-service teachers' engagement with decolonised curricular activities which respond to food insecurity?"

Food gardening has been practiced in several educational settings for different reasons. Oman food gardens were established in several schools to encourage young people to pursue healthier diets, with a view to preventing lifestyle diseases (Ambusaidi, Al-Yahyai, Taylor, \& Taylor, 2017). The results of that project revealed that learners, who engaged in food gardening projects, developed improved scientific process skills and adopted a more positive attitude to learning about cultivating plants. Learners reported great enjoyment of hands-on, practical gardening activities outside the traditional classrooms.

Another reason for cultivating food gardens is to address food insecurity. Food insecurity among university students is prevalent in developed and developing settings. Food insecurity, in this research, is defined by referring to characteristics described by the United States Department of Agriculture (2014), which include weight loss due to low intake of calories, consuming unhealthy food, consuming a diet which is not varied, consuming food which may be rich in calories and poor in nutrients. In the US, the prevalence of food insecurity among university students was found in one research study to exceed that of the population in general (Goldrick-Rab, Richardson, Schneider, Hernandez, \& Cady, 2018; Henry, 2017). Henry (2017) conducted an ethnographic study among food insecure students in Texas and found that silence, stigma, shame and facelessness was associated with food insecurity. Food insecure students reported a sense of embarrassment when they accompanied food secure students to restaurants and were unable to order food because they had no money. This resulted in them hesitating or refusing to accompany food secure students on future outings. In an Australian study, Hughes, Serebryanikova, Donaldson and Leveritt (2011) found that more than $46 \%$ of students suffered from some form of food insecurity, and that financial insecurity heightened students' risk for food insecurity. Globally, the reasons for a rise in food insecurity among students includes the fact that increasingly students are non-white, first-generation college or university students, and work in full time employment (Henry, 2017). 
Internationally, access to nutritious, adequate food is perceived to be a human right. Within the South African context, impressive legislation which is underpinned by a social justice ideology and which underscores human rights was introduced after the ushering in of the democratic order in 1994. Despite positive advancements on socio-economic and political fronts, vast material inequalities persist, and the chronic inability of poor people, especially those who emerge from rural settings, to consume a healthy diet, has been documented (Munro et al., 2013a). The link between a student's demographic profile and the likelihood of being food insecure was also found to be the case by Van den Berg and Raubenheimer (2015). Their study, which was conducted at the University of the Free State, revealed that male students from the black or coloured race groups were more vulnerable to food insecurity. Being a firstgeneration student who was unmarried or unemployed also increased students' risk for food insecurity ( $(\mathrm{bid})$. These authors argued that food insecurity contributed to low retention rates in South African universities. A study undertaken at the University of KwaZulu-Natal by Kassier and Veldman (2013) revealed that more than 12\% of students who received financial aid were food insecure, and that most of the students who were sampled suffered food deprivation more acutely towards the end of the semester. Some students reported not having consumed a substantial meal in seven days. The struggle experienced by students in tertiary education in South Africa was rendered visible by unprecedented student protests from 2015 to 2017. This coincided with calls for free higher education and decolonising of the curriculum (Jansen, 2017b; Molefe, 2016).

\section{Decolonising the University Curriculum}

Different intellectual actors in different institutional and historical contexts generated different meanings of "decolonisation" (Sayed, Motala, \& Hoffman, 2017). Sayed et al. described decolonisation as a "process of expanding imaginations" focusing on what is "relevant, rigorous scholarship" (2017, p. 61). Scholars should focus on the numerous undercurrents of the rules of scholastic excellence, such as knowledges which privilege particular race, gender and linguistic groups, and people who are located in particular parts of the world (Sayed et al., 2017). These researchers, writing in the South African context, underscored the value of African-centred content, languages and methods of teaching, in order to decolonise curricula. The exploration of the meaning of "decolonised curricula" held by teacher educators, included: decolonisation enables a deeper understanding of one's academic self, in relation to the world; it makes visible those constraints which result from the dominance of Western ways of thinking; and it involves being explicit about what South Africans can contribute to the world in terms of our unique knowledge and cultural heritage (Sayed et al., 2017). Molefe (2016, p. 32) described decolonisation as the "ending of domination of Western traditions, histories and figures". For Letsekha (2013) it is a "fundamental overhaul of the whole epistemological model underlying the current education system" (2013, p. 9). During the student protests which swept South Africa in 2015 and 2016, the call for decolonising the curriculum was expressed in the mission statement of the student movement named RhodesMustFall (sic) which claimed that "racialized patriarchy, racially and gendered barriers to the public sphere ... exploitation of black workers" as well as the production of gendered and race-based knowledge is rooted in colonial education (Sayed et al., 2017, p. 60).

Jansen (2017b) has adopted a more critical approach when interrogating the concept of a "decolonial curriculum". Jansen pointed to the "conceptual clumsiness" (2017b, p. 9) which characterises the discourse on decolonisation. This researcher argued that the understanding of a colonial curriculum has been parochial, and suggestive of evil Western curriculum versus 
Oluwakemi Ayodeji ADEBAYO, Ronicka MUDALY. Creating a decolonised curriculum to address food insecurity among university students

\section{PROBLEMS \\ OF EDUCATION \\ IN THE $21^{\text {st }}$ CENTURY Vol. 77 , No. 1, 2019 \\ 182}

noble African curriculum. Within South African universities, decolonisation of the curriculum has occurred to some extent, according to Jansen (2017b). Jansen referred to African scholars who partnered with international colleagues, such as Bongani Mayosi whose research focus is cardiovascular disease, and Quarraisha Abdool Karim and Salim Karim who collaborate with partners from international universities on AIDS research. For Jansen (2017b), collaborations in which researchers from the South are the key players and senior collaborators, and control the projects, signal a form of decolonisation in higher education. Connell (2016) concurred by adding that intellectual agendas which are not constrained by Northern hegemony are a means towards decolonisation. Jansen (2017b, p. 3) contended that in order to decolonise curricula, black theorists across different disciplines, who are "intellectually imaginative", who write books and who use innovative methods to express alternative ways of teaching and learning, are required. The challenge to decolonising the university to enhance its responsiveness to the needs of South Africa has been succinctly expressed by Pillay (2015, p. 2), who asked: "If the struggle for political and economic transformation asks 'Where are our black students and where are our black professors?', the struggle against epistemic violence adds: 'and what are we teaching and researching and how are we doing that and why are we doing that?"'

At a university seminar in 2017, Jansen (2017a) stated that the ideal situation would be for the curriculum to be strengthened in order to respond to peoples' needs, by using knowledge from Africa, Asia, and other countries, alongside knowledge from the West. Connell (2016) supported this notion of mutual learning which draws on various knowledge projects and traditions, to enable students to achieve a wider range of competencies. Connell (2016) and Jansen (2017a) cautioned against simplistic dualisms (for example, colonial versus indigenous) because worldwide problems of knowledge are not embedded solely in colonialism. Jansen (2017a) decried the quixotism of activists who provide an idyllic picture of the ethnic past and drew attention to the pre-colonial African education system which he said was patriarchal, undemocratic and authoritarian. The debates about decolonising the curriculum are embedded in critical theory, which underpinned this research.

The literature review has revealed two crucial issues. First, food insecurity occurs among university students in developed and developing contexts. In South Africa, several students' tuition is funded, but their academic progress is retarded due to their inability to sustain themselves with nutrient-dense food. Students' suffering within the higher education landscape has been rendered more visible by student protests from 2015 to 2017. These protests provided an impetus to the second issue, which is the discourse about decolonisation in higher education. What is missing from these debates is how food insecurity can be practically addressed by university students, using a decolonised curriculum.

\section{Research Methodology}

\section{General Background}

A qualitative methodology underpinned this research. This was appropriate because it allowed for generation of "data on naturally occurring phenomena. Most of the data are in the form of words rather than numbers, and in general, the researcher must search and explore with a variety of methods until a deep understanding is achieved" (McMillan \& Schumacher, 2006, p. 23). Cohen, Manion and Morrison (2011) asserted that qualitative research provides an indepth, thorough understanding of ideas, and "gives voices to participants and probes issues that lie beneath the surface of presenting behaviours and actions" (p. 219).

This research was informed by a critical paradigm. Traditionally, critical theory has been valued for exposing what social relationships concealed, for example, the connectedness of knowledge, wealth and power (Giroux, 2017). Modern critical theorists focus on the usefulness 
of critical theory in adopting interdisciplinary forms of theoretical currents to address human deprivation and suffering. Giroux (2017, p. 38) focussed on dialectic thought, which is constitutive of critical theory, and which can "reveal the power of human activity and human knowledge as both a product of and force in the shaping of social reality". Critical theory can lead to the transformation of groups of people (Bertram \& Christiansen, 2013; Rasmussen, 1999) and human emancipation (Giroux, 2017).

An illustrative case study approach was adopted in this study. According to Yin (2009, p. 18) "a case study is an empirical inquiry that investigates a contemporary phenomenon indepth and within its real-life context". Opie (2004) added that a case study approach is useful because it enables researchers to conduct a deep exploration of the lived experiences of people who form a particular case. Hayes, Kyer and Weber (2015) stated that an illustrative case study involves describing the events related phenomenon under investigation, and reasons for these events. These researchers emphasised that detailed information should be provided about the research site, participants, and goals, and that visually descriptive data should be included.

This research involved pre-service biology teachers who had participated in a field trip and had been lectured to by a traditional knowledge holder on African medicinal plants, as well as by permaculture experts. It also involved pre-service non-biology teachers who lived at residences on the campus. The pre-service biology teachers were invited to volunteer to participate in the study. They were divided into six groups and each group developed managed a food garden comprising three beds of about 80 inches (2.032 meters) length by 36 inches (0.9144 meters) width; the size of a standard door frame. To be selected to participate they were expected to be available on some weekends/holidays and be willing to plant and maintain a food garden plot until harvest. Each group of six pre-service biology teachers partnered with the 2 pre-service non-biology teachers. The pre-service biology teachers selected pre-service non-biology teachers; the latter having been self-classified as being food insecure. The groups of pre-service biology teachers developed portfolios of evidence and were interviewed in focus group interviews (FGIs), and individual interviews (IIs). Pre-service non-biology teachers volunteered to be part of the research and participated in the interviews and they maintained reflective diaries to document their experiences during the project. Each group of two residence pre-service non-biology teachers worked with a group of six pre-service biology teachers cultivating and maintaining the food garden.

\section{Sample}

A qualitative case study approach was adopted to explore how pre-service science teachers, studying a module called Biological Science for Educators 310, embarked on a garden project which was aimed at creating food security among university students. The duration of the project was four months (from February 2017 to May 2017). During this period, preservice teachers studied the topic Nutrition. The participants in this study were 36 pre-service biology teachers and 12 pre-service non-biology teachers. Convenience and purposive sampling techniques were used to recruit participants. Convenience sampling entails selecting people as participants because of their proximity (Cohen, Manion, \& Morrison, 2011). The biology students were purposively selected from the registered stream of students in a module named Biological Science for Educators 310, which was offered during the first semester in the 2017 academic year at a university in South Africa. 
Oluwakemi Ayodeji ADEBAYO, Ronicka MUDALY. Creating a decolonised curriculum to address food insecurity among university students

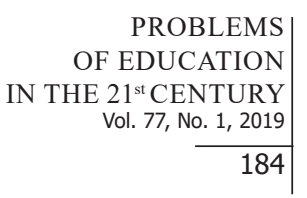

\section{Instrument and Procedures}

Qualitative data generation methods, which were employed included focus group interviews, individual interviews and the development of portfolios of evidence. Six focus groups were formed from the 36 pre-service biology teachers. In this research, participants in the focus groups discussed issues in a more conversational, unstructured manner and this allowed for deeper insights to emerge. According to Check and Schutt (2012, p. 88), focus group interviews are "A qualitative method that involves unstructured group interviews in which the focus group leader actively encourages discussion among participants on the topic of interest". The small number of six participants per group was effective in generating exploratory data. One member from each of the six focus groups participated in individual interviews. McMillan and Schumacher (2010) explained that individual interviews are good for respondents because they can easily contribute information and are confident enough to express themselves coherently. These data generation strategies provided insight into how the food gardening activity had influenced the transformation and empowerment of the participants. The final source of data was in the form of student portfolios. Portfolios encourage reflective learning and enquiry (Elango, Jutti, \& Lee, 2005). In this study, the maintenance of student portfolios by the preservice biology teachers enabled them to document their learning both in words and in pictures. This strengthened the credibility of the research data and improved triangulation of the data.

\section{The Garden Project}

The garden project was part of a larger research study titled "Exploring university community engagement by pre-service science teachers through the study of a Biology module". Pre-service biology teachers constructed knowledge about nutrition by engaging in lectures, field trips, seminars and practical work. Knowledge traditions from Western and African systems had informed these activities. Pre-service biology teachers were then given the following instructions in three parts:

\section{Part A}

Work in groups of six members. Discuss the importance of balanced nutrition for maintenance of good health among university students.

Interview students at the residences and enquire about the health problems they suffer. Select a health problem experienced by the students and conduct research on the nutrients which are required to manage or reverse the health problem/condition.

Read about plant food sources which contain the nutrients required to address the health condition, with a view to cultivating such plants.

Select three types of plants which you will cultivate. At least one of these should be an African indigenous plant. 
Oluwakemi Ayodeji ADEBAYO, Ronicka MUDALY. Creating a decolonised curriculum to address food insecurity among university students

Part B

Select two non-Biology students from the residence to work with your group. You will be required to develop gardens for food insecure students, and simultaneously teach the non-Biology students about creating food gardens.

Work with these non-Biology students throughout this project.

Part C

Select a garden plot and demarcate it.

Based on knowledge of permaculture and African indigenous knowledge, prepare the beds, sow the seeds, control pests, use nutrients to nourish the plants, and maintain the garden. You are required to prepare a portfolio of evidence to document the processes of food gardening, your experiences and reflections.

In your reflection, describe how Biology pre-service teachers can engage in university community service, such as developing food gardens for food insecure students. Describe your views about developing resilience in poor communities through food gardens. Describe how this project has transformed you as a pre-service Biology teacher.

\section{Data Analysis}

Content analysis was used to derive themes from the data sets. In analysing the data, research rigour was considered. Cresswell (2012) asserted that validating findings require that the researcher assess "accuracy or credibility" through "triangulation and member checking" (p. 259). In this research multiple data generation strategies and instruments were used to enhance validity, including individual interviews, focus group interviews, maintenance of reflective diaries and the development of portfolios. Themes from the different data sources allowed for triangulation. The interview transcripts and analysis of these were presented to the participants to corroborate these as a true reflection of their experiences and words. According to Kvale and Brinkmann (2009), reliability of research findings is closely linked with dependability. These researchers explained that if other people conducted the same study with similar participants and in a similar context, the findings should be similar. In this research, dependability was enhanced by providing detailed descriptions of the research design and process, to enable other researchers to replicate the research.

The following abbreviations were used to distinguish among sources of data:

Focus Group Interview - FGI

Individual Interview - II

Pre-service biology teacher - PBT

Pre-service non-biology teacher - PNBT

An example of a code for a participant is:

FG3 PNBT1: Focus Group three, Pre-service non-biology teacher 1

II PBT4: Individual interview, Pre-service biology teacher 4 
Oluwakemi Ayodeji ADEBAYO, Ronicka MUDALY. Creating a decolonised curriculum to address food insecurity among university students

\author{
PROBLEMS \\ OF EDUCATION \\ IN THE $21^{\text {st }}$ CENTURY \\ Vol. 77 , No. 1, 2019 \\ 186 Research Results
}

Four themes emerged from the data sets: consciousness raising about students' diets, using African indigenous knowledge to address the university students' condition of food insecurity, empowering students through knowledge of food gardening, and transformation of students.

\title{
Consciousness Raising about Students' Diets
}

Pre-service biology teachers found that many students consumed unhealthy, kilojoule dense, nutrient poor food. This was attested to in the following reflection:

Students are facing the problem of having no choice when it comes to nutrition or food they eat because of financial issues. They normally eat junk food as it is cheap. (Portfolio D)

Financial constraints were linked to poor nutrition among university students. In addition, food insecurity affected students' academic work, as was attested to by one of the participants in the following excerpt.

It a problem when you have to worry about food and have to worry about your academic performance ... it very hard ... (FG3 PBT1)

This confirms the point made by Munro, Quayle, Simpson, \& Barnsley (2013b) who studied food insecurity among students at the University of the Free State and found that students experienced great anxiety about the source of their next meal.

Then when it's time that I have to be in class and participate and be active you may find that these food (junk) it adds to the...it adds to less contribution in classes and affects us (concentration) ... the junk we eat. But then I can ...this garden could help a lot if you can. (FG1 PNBT2)

\section{Using African Indigenous Knowledge to address the University Students' condition of Food Insecurity}

Pre-service teachers conducted research about health problems suffered by students, and found that influenza, hypertension, poor vision, and anaemia were common conditions. They conducted literature searches to determine which nutrients were required to manage these conditions. They then read about the indigenous and non-indigenous food crops which contain these nutrients, and also drew on information they had gained during a field trip from an indigenous knowledge holder. Pre-service biology teachers' construction of knowledge of the nutrients contained in the crops, and disorders which supplementation can address, came from dominant forms of science knowledge which are rooted in Western scientific traditions, as well as African indigenous knowledge systems that they had learnt about during a field trip. They then cultivated food gardens which comprised indigenous and non-indigenous plants. Table 1 presents a summary of data from the portfolios of groups B, C and D regarding the indigenous crops (spinach, cabbage and amadumbi) they chose, and the reasons for selection. 
Oluwakemi Ayodeji ADEBAYO, Ronicka MUDALY. Creating a decolonised curriculum to address food insecurity among university students

Table 1. Choice of African indigenous crops.

\begin{tabular}{lll}
\hline African indigenous crop & $\begin{array}{l}\text { Health condition ad- } \\
\text { dressed by consuming } \\
\text { this food }\end{array}$ & Health-promoting properties of crop \\
\hline $\begin{array}{l}\text { Spinach } \\
\text { Basella alba }\end{array}$ & $\begin{array}{l}\text { Hypertension } \\
\text { Poor vision }\end{array}$ & $\begin{array}{l}\text { Contains magnesium to lower blood pressure. } \\
\text { Contains Vitamin A to promote good vision. Protects } \\
\text { against damage by free radicles }\end{array}$ \\
\hline $\begin{array}{l}\text { Cabbage } \\
\text { Cleome gynandra }\end{array}$ & Influenza, low immunity & $\begin{array}{l}\text { Has anti-viral, anti-inflammatory and anti-bacterial } \\
\text { properties. Contains vitamin C which increases } \\
\text { immunity }\end{array}$ \\
\hline $\begin{array}{l}\text { Amadumbi } \\
\text { Colocasia esculenta }\end{array}$ & Poor vision & $\begin{array}{l}\text { Contains beta carotene and antioxidants to improve } \\
\text { vision }\end{array}$ \\
\hline
\end{tabular}

The following reasons were presented for selecting certain crops:

We chose mustard spinach as it helps to lower high blood pressure. Spinach is low in fat and even lower in cholesterol which is good for students as they normally eat or by food with high cholesterol. Spinach contains proteins, vitamin $A, C, E$ and $K$, iron and magnesium which helps lower blood pressure. (Portfolio D)

We conducted a survey here at Edgewood and discovered some students who wear glasses are also affected by night blindness. A person who suffers from night blindness has a deficiency of vitamin A. Vitamin A helps in the development of healthy skin and nerve tissue, functions in the eye sight and bone formation. (Portfolio B)

The students from poor socioeconomic backgrounds can benefit a lot from these garden project, especially since the crops that are grown in this garden are highly rich in nutrition and they contain almost all the nutrients that are needed by the body. For example, carrot can boost a person's cognitive ability and restore vision, whereas beetroot has been praised by many experts and prescribed by many doctors for blood regulation and cancer, cardiovascular diseases prevention. On the other hand, the spinach is regarded as one of the crops that helps lowering high blood pressure since it contains iron and many other vitamins and minerals. (Portfolio E)

Table two shows the indigenous skills and materials derived from indigenous knowledge which were used during cultivation of the crops.

Table 2. Skills and knowledge obtained from indigenous knowledge systems.

\begin{tabular}{llll}
\hline Soil preparation & Soil nutrients & Pest control & Moisture \\
\hline $\begin{array}{l}\text { Removing weeds by } \\
\text { hand }\end{array}$ & $\begin{array}{l}\text { Kraal manure, horse } \\
\text { manure and sawdust }\end{array}$ & $\begin{array}{l}\text { Dusting of wood ash, covering } \\
\text { crops with a net }\end{array}$ & $\begin{array}{l}\text { Feeling soil with hands } \\
\text { to determine moisture } \\
\text { content }\end{array}$ \\
\hline $\begin{array}{l}\text { Using a spade and hoe } \\
\text { to reduce compaction } \\
\text { of soil }\end{array}$ & $\begin{array}{l}\text { Fruit and vegetable } \\
\text { peelings mixed with soil, } \\
\text { dried leaves }\end{array}$ & $\begin{array}{l}\text { Mixed cropping } \\
\text { Planting three different types of } \\
\text { crops in one area Planting garlic, } \\
\text { onions and marigolds on the bor- } \\
\text { ders to repel insects }\end{array}$ & $\begin{array}{l}\text { Cans with small holes } \\
\text { for watering }\end{array}$ \\
\hline
\end{tabular}

Photographs were also used to capture stages in the development of gardens, as shown in Figure 1 and Figure 2. 
Oluwakemi Ayodeji ADEBAYO, Ronicka MUDALY. Creating a decolonised curriculum to address food insecurity among university students

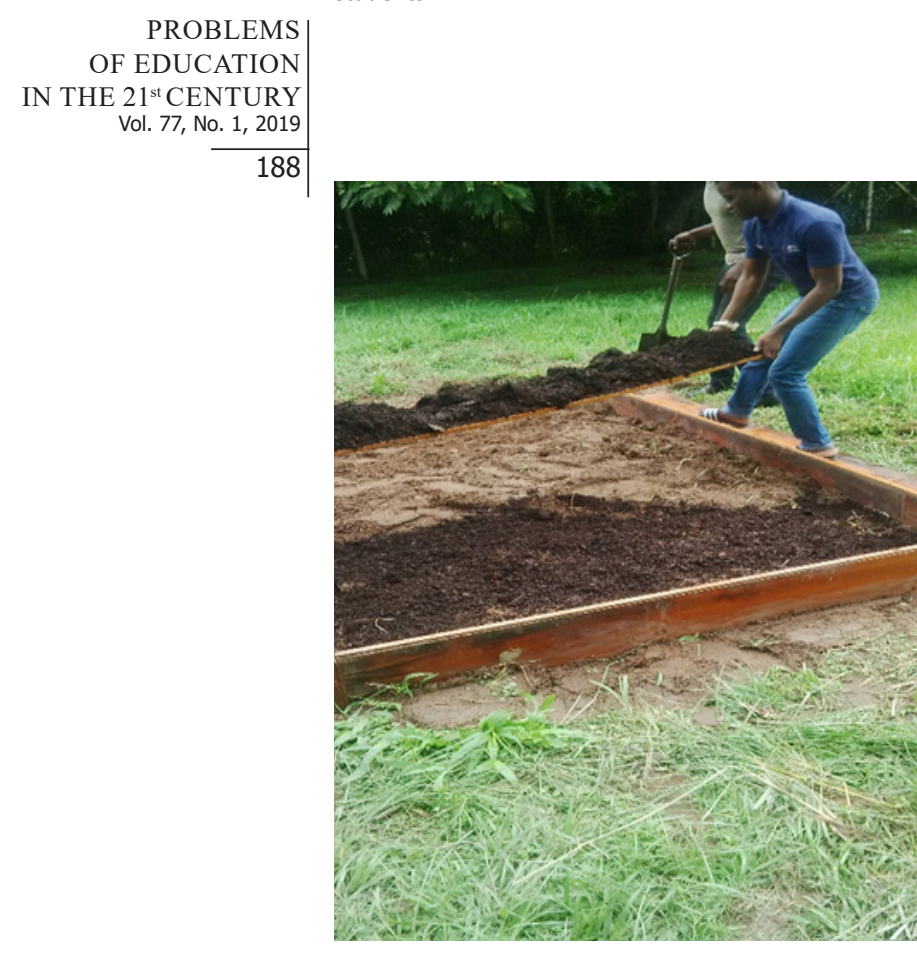

Figure 1. Bed preparation

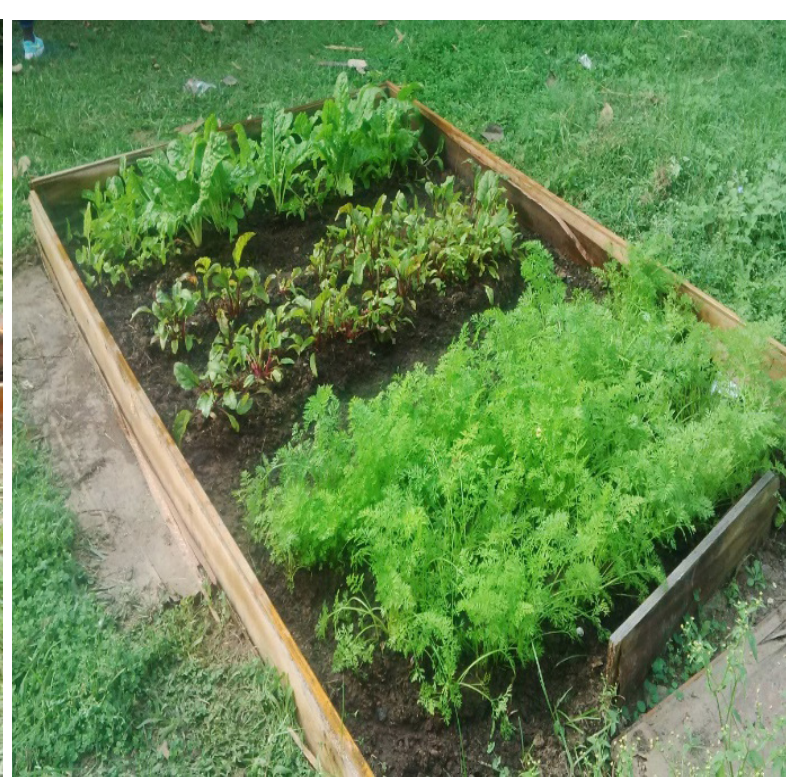

Figure 2. Mature, mixed crops

The pre-service biology teacher participants had acquired gardening knowledge and skills during a field trip which preceded this activity, as well as from familiar Western sources, including textbooks and online learning videos. Custodians of African indigenous knowledge, as well as permaculture experts, had served as teachers of the gardening activity during the field trip. The participants in this research obtained information about health problems from residence students and researched the types of nutrients from Western and alternative knowledge sources, which could be used to manage these disorders. Based on this information, they cultivated African indigenous and non-indigenous crops to address the health disorders. Pre-service teachers used simple instruments, such as spades and hoes, and their hands (see Figure 1), to prepare the garden beds. They viewed mixed cropping as essential for sustainable gardening, and a useful way to deter pests (see Figure 2).

\section{Empowering Students through Knowledge of Food Gardening}

Pre-service teachers believed that both they and the non-biology students were empowered by engaging in the gardening activity. The following excerpts attest to this:

Even though they are facing a challenge of a balanced diet they (university students) also don't really know how to plant their own vegetables, which can actually help them a lot instead of going to the market to buy. Engaging such students in a garden project can actually help them learn how to plant and look after their vegetables and crops to fight the ignorance and starvation. (Portfolio D)

I think if ... if many students can be involved in such projects like everyone in the university maybe make it like a compulsory module or something because it will help students to have something to rely on like whenever there's a shortage of vegetables or food. They know that they have a garden instead of going to shop to buy or worrying about where they going to get the money to buy food and vegetables and stuff. (II PBT4) 
Oluwakemi Ayodeji ADEBAYO, Ronicka MUDALY. Creating a decolonised curriculum to address food insecurity among university students

Students who are coming from disadvantaged backgrounds in a way that nobody can see that they are suffering ... they will get food, healthy food in the project like this, and they will focus on their PROBLEMS OF EDUCATION IN THE $21^{\text {st }}$ CENTURY Vol. 77, No. 1, 2019 studies with their stomachs full and, they will sell the crops and get money like other students who are coming from rich backgrounds. (II PBT5)

Similar views about self-reliance were echoed by pre-service non-biology teachers.

You'll find that people will become dependent on themselves and not on the government and they wouldn't have to buy food or vegetables that they usually buy. They will be able to plant their own food. Yes ... (II PNBT1)

I've been empowered in terms of skills. I've gained some skills to ... how you can set up the garden basically ... I am being empowered. (FG1 PNBT2)

Pre-service teachers valued the gardening activity, for its potential to free students from hunger, and make them more self-reliant. They believed that they could take care of their nutritional well-being, because they had acquired skills and knowledge related to planting of vegetable crops. Arroyo (n.d) summed up the empowering value of food gardening to address food insecurity by stating that this is a form of cultivating self-reliance. The potential for food self-reliance through urban gardening was also underscored by Grewal and Grewal (2011).

\section{Transformation of Students}

The empowerment which was borne of knowledge and skills related to the garden project, created a change in students. They believed that they could become more self-reliant and enable their communities to do the same, as is evident in the following excerpts:

Students like myself can ... they should be engaged because students like myself are young, and they ... they have energy, they've got power, actually we are the ones to stand up for our communities so, if we students like myself come together make a garden that would hmm ... it would reduce food insecurity ... (II PBT6)

It can bring intellectual freedom from the bondage of poverty since we rely mostly on ... mostly on the jobs ... that you have to find a job to feed your family. So this project, the gardens you'll know that in order to feed your family you have to go and have your own garden. (FG1 PBT4)

\section{Discussion}

In this research, pre-service biology teachers' awareness about students' diets was enhanced. They found that students consumed nutrient poor, calorie rich, inexpensive food because they were financially deprived. A possible reason for their enhanced awareness was that pre-service teachers were guided, through module activities, to actively investigate students' diets. The research by Ambusaidi, Al-Yahyai, Taylor and Taylor (2017) also revealed that food gardening could be used as a pedagogical resource within the science curriculum to obtain deeper insights into diet and health. In another research project, Martinez, Maynard and Ritchie (2016) found that students consumed food which was cheap and nutritionally sparse due to their limited financial resources. Participants in this research reported decreased levels of concentration in class due to food insecurity. In a research project by Taras (2015), it was also revealed that nutrient insufficiency was related directly to lower cognitive functioning. Maroto (2013) also found lower levels of concentration among food insecure students in community colleges in America, with African American students and multiracial students being more vulnerable than their white counterparts. In the research carried out by Munro 
Oluwakemi Ayodeji ADEBAYO, Ronicka MUDALY. Creating a decolonised curriculum to address food insecurity among university students

PROBLEMS

OF EDUCATION

IN THE $21^{\text {st }}$ CENTURY Vol. 77, No. 1, 2019

190

et al. (2013b), several university students attributed their diminished ability to concentrate to hunger. The negative influence of food insecurity on a variety of forms of cognitive tests (verbal memory, verbal fluency, spatial ability) was revealed in a study by Gao, Scott, Falcon, Wilde and Tucker (2009). Payne-Sturges, Tjaden, Caldeira, Vincent and Arria (2018) predicted that the poor nutrition predicament among university students could have far reaching effects on the academic achievement of students. Developing interventions to stem inadequate nutrition within the students' populace will reduce the dropout rates and increase the graduation output of students in universities (Gallegos, Ramsey, \& Ong, 2014).

Pre-service teachers were directed to explore different methods of gardening in this research. Pre-service teachers' confidence in their ability to make a positive change to address food security can be attributed to the new knowledge and skills which they had constructed. Ambusaidi et al. (2017) observed positive changes in the affective domain of students, and an improvement in their science process skills, when they engaged in food gardening. The pre-service biology teachers learned certain strategies from non-traditional teachers in higher education (permaculture experts and an indigenous knowledge holder) included intercropping, using the hand to determine moisture content of soil, using spades and hoes to sow seeds, and using natural fertilizers and pesticides. The use of intercropping was supported by McGranahan et al. (1999), who investigated agriculture and human health in the Caribbean. These researchers found that cultivating genetically diverse crops was a useful strategy to control pests. Notsi (2012), who engaged in a research project about African indigenous farming methods, found that the hand-hoe method was effective because it allowed for accurate placement of seeds and compost, and could be used to determine soil moisture content. Notsi (2012) added that organic kraal manure enhanced soil quality by enriching it with organic and inorganic nutrients. Some pre-service teacher participants in this research used wood ash to deter pests. Dilute solutions of wood ash and urine and wood ash on its own (Notsi, 2012), is cheap, easily available, environmentally friendly and sustainable method of pest control, which is widely used in African countries.

By placing pre-service biology teachers at the centre of this research, the responsibility of learning devolved to them. Pre-service biology teachers' social exploration into the suffering of fellow students due to food insecurity raised their awareness about the nutritional consequences of a poor or insufficient diet.

This research created opportunities for decolonising the curriculum. Firstly, a curriculum activity was designed which enabled pre-service teachers to transcend familiar ways of learning. Through that curriculum activity, pre-service biology teachers were encouraged to venture into indigenous knowledge and strategies of gardening, which was then augmented with knowledge from traditional Western sources. In order to achieve this, pre-service biology teachers were trained by experts from outside the university who then served as teacher educators. A custodian of African indigenous knowledge, and permaculture experts, were engaged to do this work. Disrupting the "who" of teaching is one of the ways in which the curriculum can be decolonised.

Secondly, privileging of African indigenous knowledge content in the curriculum addressed, albeit in a minor way, epistemicide of alternative knowledge systems. Pre-service biology teachers engaged in research about indigenous plants, the nutritive value of these plants and the health problems that could be addressed by consuming products of these plants. As a result, pre-service teachers' knowledge about the value of indigenous crops was deepened. This result could be attributed to the module activity which was designed to incorporate indigenous knowledge into the curriculum. In another study in Indonesia, indigenous knowledge was integrated into the science curriculum, and resulted in more meaningful learning, and mastery of scientific concepts (Hariyadi \& Kurniawan, 2018). In addition, the employment of traditional methods of gardening, which were not prohibitively expensive, and which were environmentally friendly, sustainable, and easily accessible, was encouraged. In this way the curriculum was strengthened and decolonised (Jansen, 2017a). 
Thirdly, the curriculum activity was designed to address the university student condition of food insecurity. In order to respond to the needs of food insecure students, pre-service teachers' consciousness of these challenges was rendered wide awake, through their social inquiry from students about food quality, factors which affected food acquisition and choices, and health disorders which students experienced. This "awakening of the self" enabled preservice teachers to respond to students' needs, using the curriculum.

Fourthly, a consequence of pre-service teachers' action was empowerment and transformative learning. Cox and John (2016) underscored the value of learning which transforms people and focuses on the potential for emancipatory education within a supportive environment, where critical thinking is privileged. Mezirow (2003) indicated that transformative learning creates changes in personal and professional identities. Quijano (2007) added that this transformation can lead to the construction of an emancipatory identity. In order to address student challenges at the micro-level, a curriculum activity was designed which transformed pre-service teachers from transmitters of knowledge to "challengers, risk takers and supportative simultaneously" (Elsey, 2010, p. 1). This signalled a shift towards decolonisation. Pre-service teachers were given the opportunity to construct and apply new forms of knowledge (McGonigal, 2005) and thereby meet the needs of food insecure students. They became more critically conscious (Rodriguez, 2008) of the realities of food insecure students, and recognised their agency and capacity to respond, which was awakened through the curriculum. These changes enhanced their consciousness of social challenges, enabling them to work collaboratively and creatively while maintaining an intellectual aspect to the learning environment, and resulted in their progress towards emancipatory knowledge (Elsey, 2010).

\section{Conclusions}

The results of this research revealed how a part of the curriculum can be decolonised, thereby creating food security for students, by students (pre-service biology teachers). It also provides insight into how teaching and learning of science can transcend its relatedness to a set of facts only, by infusing it with ethical commitment. While leading education analysts search for radical African intellectuals who can finally purge the curriculum of the alienation and subordination of African people, this research has illustrated how the curriculum can be strengthened by drawing on intellectual authorities of different knowledge traditions. Curricular activities were decolonised, and epistemic justice was sought, by utilising opportunities for teaching and learning about African indigenous plants from African indigenous knowledge holders and other experts. In this way, dominant notions of legitimate knowledge and legitimate knowledge holders were disrupted. These activities raised pre-service teachers' consciousness of the social reality of food insecure students, and heightened their feelings of empowerment to enable others, and themselves, to become self-reliant and self-sufficient. This signalled a freeing of themselves from material and intellectual shackles, which are critical to decolonising thought and action in education.

\author{
PROBLEMS \\ OF EDUCATION \\ IN THE $21^{\text {st }}$ CENTURY \\ Vol. 77, No. 1, 2019 \\ 191
}


Oluwakemi Ayodeji ADEBAYO, Ronicka MUDALY. Creating a decolonised curriculum to address food insecurity among university students

\section{PROBLEMS \\ OF EDUCATION \\ IN THE $21^{\text {st }}$ CENTURY \\ Vol. 77 , No. 1, 2019 \\ 192 \\ Implications for Learning and Future Studies}

Several implications for teacher education stem from this research. The importance of embedding science teacher education in the lived experiences of people, with a view to addressing social challenges, could be a focus of modules in higher education. A socially responsive science education would have several benefits. Firstly, it could address social challenges which people encounter. Secondly, it could provide opportunities for science teachers to venture beyond facts about anatomy and physiology, when they teach about human nutrition. This could transform the professional identity of science teachers and increase their confidence to engage in socially responsible activities, using the science curriculum. Science teacher education modules could be designed in a way that fosters epistemic justice through a transformed curriculum. Future research could explore ways of incorporating indigenous knowledge into mainstream higher education science curricula. In addition, the engagement of other experts, who are not commonly featured in higher education, such as indigenous knowledge experts, could be areas of future research.

\section{Acknowledgements}

Funding received in 2017 from the National Research Foundation (South Africa) is acknowledged. Photographs courtesy of Cacisani Duma (Figure 1) and Khethani Buthelezi (Figure 2).

\section{References}

Ambusaidi, A., Al-Yahyai, R., Taylor, S., \& Taylor, N. (2017). School gardening in Oman: A pilot project with grade 7 students. International Journal of Environmental and Science Education, 12(2), 195-211.

Arroyo, A. (n.d). Empowering the Palouse: Growing food, educating and cultivating self-reliance. Retrieved from https://www.northwestharvest.org/stuff/contentmgr/files/0/11e50e10fde6c5a02d6 337f798e4abd5/files/whitman_cac_final.pdf.

Bertram, C., \& Christiansen, I. M. (2013). Understanding research: An introduction to reading research. Pretoria: Van Schaik.

Check, J., \& Schutt, R. K. (2012). Research methods in education. London: Sage.

Cohen, L., Manion, L., \& Morrison, K. (2011). Research methods in education (7th ed.). London: Routledge.

Connell, R. (2016). Decolonising knowledge, democratising curriculum. University of Johannesburg Retrieved from https://www.uj.ac.za/faculties/humanities/sociology/PublishingImages/Pages/ Seminars/Raewyn\%20Connell's\%20Paper\%20on\%20Decolonisation\%20of\%20Knowledge.pdf.

Cox, A. J., \& John, V. M. (2016). Transformative learning in postapartheid South Africa: Disruption, dilemma, and direction. Adult Education Quarterly, 66(4), 303-318. https://doi. org/10.1177/0741713616648376.

Creswell, J. W. (2012). Educational research: Planning, conducting, and evaluating quantitative and qualitative research (4th Ed.). Boston, MA: Pearson.

Dominguez-Whitehead, Y. (2015). Students' food acquisition struggles in the context of South Africa: The fundamentals of student development. Journal of College Student Development, 56(3), 292308.

Elango, S., Jutti, R. C., \& Lee, L. K. (2005). Portfolio as a learning tool: Students' perspectives. Annals of Academic Medicine Singapore, 34(8), 511-513.

Elsey, M. (2010). The transformative educator: Sustaining initiatives in adult teaching and learning. Retrieved from https://msu.edu/ mwr2p/Elsey-MR2P-2010.pdf.

Gallegos, D., Ramsey, R., \& Ong, K. W. (2014). Food insecurity: Is it an issue among tertiary students? Higher Education, 67(5), 497-510. 
Oluwakemi Ayodeji ADEBAYO, Ronicka MUDALY. Creating a decolonised curriculum to address food insecurity among university students

\begin{tabular}{l} 
PROBLEMS \\
OF EDUCATION \\
IN THE 21 $1^{\text {st }}$ CENTURY \\
Vol. 77, No. 1, 2019 \\
\hline 193
\end{tabular}

Gao, X., Scott, T., Falcon, L. M., Wilde, P. E., \& Tucker, K. L. (2009). Food insecurity and cognitive function in Puerto Rican adults. The American Journal of Clinical Nutrition, 89(4), 1197-1203. doi: 10.3945/ajen.2008.26941.

Giroux, H. A. (2017). Critical theory and educational practice. In A. Darder, R. D. Torres, \& M. P. Baltodano (Eds.), The critical pedagogy reader (pp. 27-51). New York: Routledge.

Goldrick-Rab, S., Richardson, J., Schneider, J., Hernandez, A., \& Cady, C. (2018). Still hungry and homeless in College. Retrieved from https:/hope4college.com/wp-content/uploads/2018/09/ Wisconsin-HOPE-Lab-Still-Hungry-and-Homeless.pdf.

Grewal, S. S. \& Grewal, P. S. (2011). Can cities become self-reliant in food? Cities, (29), 1-11.

Hayes, R., Kyer, B. \& Weber, E. (2015). A Case Study Cookbook. Retrieved from https://web.wpi.edu/ Pubs/E-project/Available/E-project-121615-164731/unrestricted/USPTO_CookbookFinal.pdf.

Henry, L. (2017). Understanding food insecurity among college students: Experience, motivation and local solutions. Annals of Anthropological Practice, 41(1), 6-19. https://doi.org/10.1111/napa.12108.

Hariyadi, B., \& Kurniawan, D. A. (2018). Deceiving the queen: Integrating Jambinese traditional honey gathering into science learning. Biodik, 4(2), 60-76. DOI: https://doi.org/10.22437/bio.v4i2.5870.

Hughes, R., Serebryanikova, I., Donaldson, K., \& Leveritt, M. (2011). Student food insecurity: The skeleton in the university closet. Nutrition and Dietetics, 68(1), 27-32. https://doi.org/10.1111/ j.1747-0080.2010.01496.x.

Jansen, J. (2017a). "The problem with decolonisation": Paper presented at a seminar at Stellenbosch University, South Africa, on 30 November 2017. Retrieved from http://www.litnet.co.za/problemdecolonisation-jonathan-jansen-seminar.

Jansen, J. (2017b). Introduction-Part II. Decolonising the university curriculum given a dysfunctional school system? Journal of Education, 68, 4-13.

Kassier, S., \& Veldman, F. (2013). Food security status and academic performance of students on financial aid: The case of University of KwaZulu-Natal. Alternation, 9, 248-264.

Kumo, W. L., Omilola, B., \& Minsat, A. (2015). South Africa 2015: African Economic Outlook. Retrieved from https://www.norfund.no/getfile.php/134019-1484665184/Bilder/Publications/AEO2015 EN.pdf.

Kvale, S., \& Brinkmann, S. (2009). Interviews: Learning the craft of qualitative research interviewing (2nd Ed.). Los Angeles, CA: Sage.

Letsekha, T. (2013). Revisiting the debate on the Africanisation of higher education: An appeal for a conceptual shift. The Independent Journal of Teaching and Learning, 8(1), 5-18.

Maroto, M. E. (2013). Food insecurity among community college students: Prevalence and relationship to GPA, energy and concentration. (Unpublished doctoral thesis) D, Morgan State University, Baltimore, Maryland, United States.

Martinez, S. M., Maynard, K., \& Ritchie, L. D. (2016). Student food access and security study: University of California. Retrieved from http://regents.universityofcalifornia.edu/regmeet/july16/e1attach. pdf.

McGonigal, K. (2005). Teaching for transformation: From learning theory to teaching strategies. Speaking of Teaching, 14(2), 1-4.

McGranahan, G., Lewin, S., Fransen, T., Hunt, C., Kjellen, M., Pretty, J., Stephens, C., \& Virgin, I. (1999). Environmental change and human health in countries of Africa, the Caribbean and the Pacific. Retrieved from https://mediamanager.sei.org/documents/Publications/Risk-livelihoods/ environmental_change_human_health_africa.pdf.

McMillan, J. H., \& Schumacher, S. (2006). Research in Education. Evidenced-Based Inquiry (6th Ed.). New Jersey: Pearson Education.

McMillan, J. H., \& Schumacher, S. (2010). Research in education: Evidence-based inquiry (7th Ed.). Upper Saddle River, NJ: Pearson Education.

Mezirow, J. (2003). Transformative learning as discourse. Journal of Transformative Education, 1(1), 58-63. https://doi.org/10.1177/1541344603252172.

Molefe, T. O. (2016). Oppression Must Fall: South Africa's Revolution in Theory. World Policy Journal, 33(1), 30-37. http://dx.doi.org/10.1215/07402775-3545858.

Munro, N., Quayle, M., Simpson, H., \& Barnsley, S. (2013a). Hunger for knowledge: Food insecurity among students at the University of KwaZulu-Natal. Perspective in Education, 31(4), 168-179. 
Oluwakemi Ayodeji ADEBAYO, Ronicka MUDALY. Creating a decolonised curriculum to address food insecurity among university students

PROBLEMS
OF EDUCATION
IN THE 21 ${ }^{\text {st }}$ CENTURY
Vol. 77 , No. 1, 2019
$\frac{194}{194}$

194

Munro, N., Quayle, M., Simpson, H., \& Barnsley, S. (2013b). Hunger for knowledge: Food insecurity among students at the University of KwaZulu-Natal. Retrieved from http://apps.ufs.ac.za/media/ dl/userfiles/documents/News/2015/2015_08/UKZN\%20Hunger\%20for\%20knowledge.pdf.

Notsi, L. (2012). African indigenous farming methods used in the cultivation of African indigenous vegetables: A comparative study of Tsitas Nek (Lesotho) and Mabeskraal Village (South Africa). Retrieved from http://docplayer.net/34656048-By-1-notsi-department-of-anthropology-school-ofsocial-sciences-and-development-studies.html.

Opie, C. (2004). Doing educational research: A guide for first time researchers. London: Sage.

Payne-Sturges, D. C., Tjaden, A., Caldeira, K. M., Vincent, K. B., \& Arria, A. M. (2018). S Student hungeroncampus:Foodinsecurity among collegestudents and implications foracademicinstitutions. American Journal of Health Promotion, 32(2), 349-354. doi: 10.1177/0890117117719620.

Pillay, S. (2015). Decolonizing the university. Retrieved from http://africasacountry.com/2015/06/ decolonizing-the-university/.

Quijano, A. (2007). Coloniality and modernity/rationality. Cultural Studies, 21(2-3), 168-178. https://doi. org/10.1080/09502380601164353.

Rasmussen, D. M. (1999). The handbook of critical theory. Oxford: Blackwell Publishers.

Rodriguez, A. (2008). Towards transformative teaching practice: Criticity, pedagogy and praxis. The International Journal of Learning, 15(3). Retrieved from https://core.ac.uk/download/ pdf/61744390.pdf.

Sayed, Y., Motala, S., \& Hoffman, N. (2017). Decolonising initial teacher education in South African universities: More than an event. Journal of Education, (68), 59-91.

Taras, H. (2015). Nutrition and student performance at school. Journal of School Health, 75(6), 199-213. doi: $10.1111 / \mathrm{j} .1746-1561.2005 .00025 . x$.

United States Department of Agriculture. (2014). Definitions of food security. Retrieved from https:// www.ers.usda.gov/topics/food-nutrition-assistance/food-security-in-the-us/definitions-of-foodsecurity.

Van den Berg, L., \& Raubenheimer, J. (2015). Food insecurity among students at the University of the Free State, South Africa. The South African Journal of Clinical Nutrition, 28(4), 160-169.

Van Zyl, A. (2015). The FYE and the SANRC: Institutional approaches to the first year. Paper presented at the UKZN AMS Colloquium on November 16, 2015 at University of KwaZulu-Natal, South Africa.

Yin, R. K. (2009). Case study research: Design and methods (4th Ed.). Los Angeles: Sage.

Received: December 31, 2018

Accepted: March 19, 2019

\begin{tabular}{|ll} 
Oluwakemi Ayodeji Adebayo & MEd, PhD Student, University of KwaZulu-Natal, Private Bag X03, Ashwood, \\
& $\begin{array}{l}\text { 3605, South Africa. } \\
\text { E-mail: kadebayo_fds@yahoo.com }\end{array}$ \\
\hline Ronicka Mudaly & $\begin{array}{l}\text { PhD, Associate Professor in Science and Technology Education Cluster, } \\
\text { University of KwaZulu-Natal, Private Bag X03, Ashwood, 3605, South Africa. } \\
\text { E-mail: mudalyr@ukzn.ac.za }\end{array}$
\end{tabular}

